\title{
Biofilter for treating toluene vapors: Performance evaluation and microbial counts behavior
}

Yazhong Zhu, Shunyi Li, Yimeng Luo, Hongye Ma, Yan Wang

A lab-scale biofilter packed with mixed packing materials was used for degradation of the toluene. Different empty bed residence time, 148.3, 74.2 and $49.4 \mathrm{~s}$ were tested for inlet concentration ranging from 0.2 to $1.2 \mathrm{~g} / \mathrm{m}^{3}$. Maximum elimination capacity of $36.0 \mathrm{~g} /\left(\mathrm{m}^{3} \mathrm{~h}\right)$ occurred at inlet loading rate of $45.9 \mathrm{~g} /\left(\mathrm{m}^{3} \mathrm{~h}\right)$. Contribution of the lower layer was higher than other layers and always had highest elimination capacity. Carbon dioxide production rate and distribution of micro-organisms followed toluene elimination capacities. Results of this study indicated that mixed packing materials could be considered as a potential biofilter carrier, with low pressure drop (less than $84.9 \mathrm{~Pa} / \mathrm{m}$ ), for treating air streams containing VOCs. 
1 Biofilter for treating toluene vapors: Performance evaluation and microbial counts behavior

2

$3{ }^{1}$ School of Chemical Engineering and Energy, Zhengzhou University, Zhengzhou 450000,

4 China

5 Corresponding Author: Shunyi Li ${ }^{1} 100$ Science Avenue, Zhengzhou 450000, China

6 Email address: Shunyi Li, 1sy76@zzu.edu.cn

7 Abstract: A lab-scale biofilter packed with mixed packing materials was used for degradation of

8 the toluene. Different empty bed residence time, 148.3, 74.2 and $49.4 \mathrm{~s}$ were tested for inlet

9 concentration ranging from 0.2 to $1.2 \mathrm{~g} / \mathrm{m}^{3}$. Maximum elimination capacity of $36.0 \mathrm{~g} /\left(\mathrm{m}^{3} \mathrm{~h}\right)$ occurred at inlet loading rate of $45.9 \mathrm{~g} /\left(\mathrm{m}^{3} \mathrm{~h}\right)$. Contribution of the lower layer was higher than

11 other layers and always had highest elimination capacity. Carbon dioxide production rate and

12 distribution of micro-organisms followed toluene elimination capacities. Results of this study indicated that mixed packing materials could be considered as a potential biofilter carrier, with 


\section{Introduction}

Large quantities of volatile organic compounds (VOCs) are emitted into atmosphere from different resources, such as chemical, petrochemical, pharmaceutical, food processing, pulp and paper mills, color printing, painting works, vehicle exhaust, waste incinerators and composting facilities (Chen et al. 2005; Slominska et al. 2013; Yassaa et al. 2006). Toluene is one of the common air pollutants in different industries. It is mutagenic and carcinogenic, and exposed to toluene might cause damage to the liver, kidney and the central nervous system (Gallastegui et al. 2011; Rene et al. 2005). According to the report of operating facilities in 2009, the rate of toluene emission into the atmosphere was $12.2 \mathrm{kt} / \mathrm{yr}$ in the USA, and $3.9 \mathrm{kt} / \mathrm{yr}$ in Canada (Gallastegui et al. 2011).

Biofilter is widely used for odor and air pollution treatment, particularly VOCs with high flow rates and pollutants concentration less than 1000 ppm (Delhomenie et al. 2003; El-Naas et al. 2014; Maestre et al. 2007; Rahul et al. 2013a; Rahul et al. 2013b; Rene et al. 2009; Singh et al. 2010a). Compared to conventional technology, biofilter is cost competitive and none secondary pollutants produced (Elmrini et al. 2004). Many references show that toluene could be used as biofilter's substrate (Aly Hassan \& Sorial 2009; Cho et al. 2009; Xi et al. 2006).

Packing materials are where physical, chemical and biological reactions occurred, thus the properties are concerned, such as high surface area and porosity for biofilm growth, suitable $\mathrm{pH}$, acceptable buffering capacity (Mudliar et al. 2010; Zare et al. 2012) and benign water-holding capacity (Anet et al. 2013). Peat, soil, compost, barks and wood chips are the commonly used organic medias (Lebrero et al. 2014). Lifespans of such organic medias are short, and may cause clogging in the long run (Dorado et al. 2010). Other medias, like perlite, vermiculite, glass beads, polyurethane foam, polystyrene and lava rock, have seldom indigenous micro-organisms and need extra nutrients (Mudliar et al. 2010).

R.S. Singh et al.(Singh et al. 2010b) evaluated the performance of a biofilter treating toluene packed with polyurethane foam. Removal efficiency ranging from 68.2 to $99.9 \%$ and elimination capacity ranging from 10.85 to $90.48 \mathrm{~g} /\left(\mathrm{m}^{3} \mathrm{~h}\right)$. Removal efficiency ranging from 40 
to $95 \%$ and elimination capacity ranging from 3.5 to $128 \mathrm{~g} /\left(\mathrm{m}^{3} \mathrm{~h}\right)$ was observed by Rene et al (Rene et al. 2005). However, few researchers focused on the behaviors of different layers contributed to the overall performances, and the relations between the microbial counts and the inlet loading rate were so clear.

The main objective of this research was to determine the removal efficiency and elimination capacity of different layers as a function of inlet loading rate and empty bed residence time in a lab scale biofilter. The production of carbon dioxide and the microbial counts of three layers were also evaluated. And the variation of the pressure drops was observed.

\section{Materials and method}

\subsection{Inoculum and packing material}

The inert material employed in the biofilter was invented by this lab (China invention patent, ZL201210446960.1), and it was mixed by compost, cement, perlite, $\mathrm{CaCO}_{3}$, plant fiber, etc. Sodium silicate was used as adhesive. The physical properties were summarized in Table 1. Fresh activated sludge was used as the inoculum source for the biofiter, which was obtained from a municipal wastewater treatment plant in Zhengzhou, China. Microorganisms in the activated sludge were acclimated to toluene in order to accelerate the adaptation period. For acclimation, one liter of the activated sludge was enclosed in an aerated tank and diluted with $3 \mathrm{~L}$ of nutrient solution (Amin et al. 2014). The composition of nutrient solution per liter of distilled water was: $\mathrm{K}_{2} \mathrm{HPO}_{4}-0.11 \mathrm{~g}, \mathrm{KH}_{2} \mathrm{PO}_{4}-0.04 \mathrm{~g}, \mathrm{NH}_{4} \mathrm{Cl}-0.54 \mathrm{~g}, \mathrm{MgSO}_{4}-0.067 \mathrm{~g}, \mathrm{CaCl}_{2}-0.036 \mathrm{~g}, \mathrm{FeCl}_{3}-0.25 \mathrm{mg}$, $\mathrm{MnSO}_{4}-0.03 \mathrm{mg}, \mathrm{ZnSO}_{4}-0.04 \mathrm{mg},\left(\mathrm{NH}_{4}\right)_{6} \mathrm{Mo}_{7} \mathrm{O}_{24} \bullet 4 \mathrm{H}_{2} \mathrm{O}-0.03 \mathrm{mg}$. Table 1 Physical properties of the mixed packing materials

\begin{tabular}{ccc}
\hline Parameter & Units & Mixed packing materials \\
\hline Equivalent diameter & $\mathrm{mm}$ & $10-12$ \\
Bulk density & $\mathrm{kg} / \mathrm{m}^{3}$ & $471.0 \pm 0.8$ \\
Specific surface area & $\mathrm{m}^{2} / \mathrm{g}$ & $3.91 \pm 0.20$ \\
Void space volume & $\%$ & $38-41$ \\
Water holding capacity & $\%$ & 52 \\
\hline
\end{tabular}

2.2 Biofilter setup and operation conditions

The biofilter was constructed from Plexiglas cylinders with an internal diameter of $105 \mathrm{~mm}$, 
67 and a total bed height of $90 \mathrm{~mm}$, which was divided into three same sections. The total bed volume was approximately 8.24 L. Figure 1 shows the schematic diagram of the biofilter system. Toluene (Kemel, 99.5\% AR Grade, China) was stripped with compressed air. The biofilter was operated in an up-flow mode at room temperature. The concentration of pollutants was fixed by means of flowmeters (all from Yuyao Kingtai instrument CO., China).

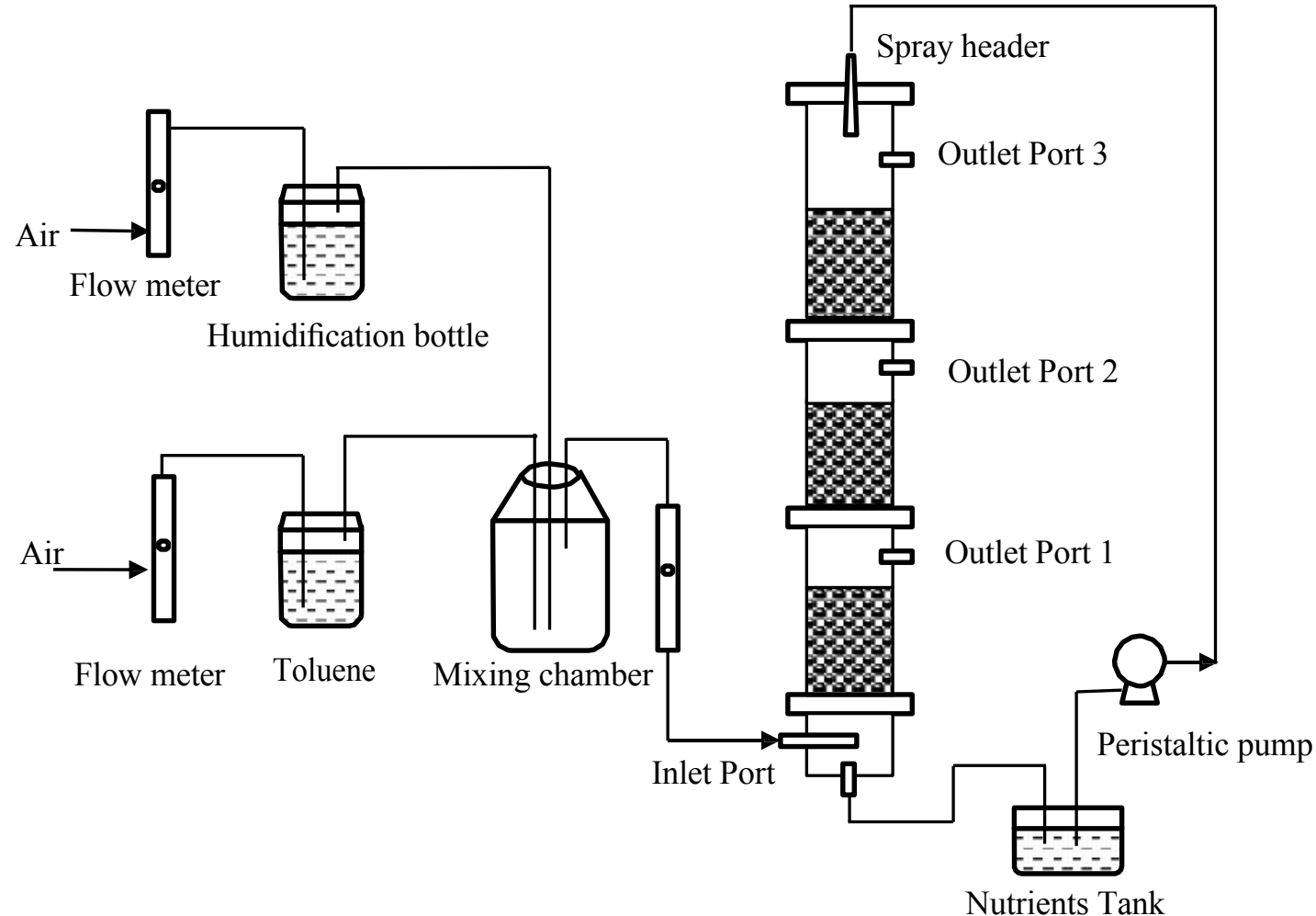

Figure 1 Schematic diagram of the biofilter system

The operating conditions of the biofilter are summarized in Table 2. During the study, different inlet loading rates (ILR), $5.0 \pm 1.0,15.2 \pm 1.8,25.6 \pm 2.9,34.4 \pm 2.0,44.5 \pm 1.5$ and $61.1 \pm 5.0$ $\mathrm{g} /\left(\mathrm{m}^{3} \mathrm{~h}\right)$, were set up at an empty bed residence time (EBRT) of $74.2 \mathrm{~s}$. Experiments at EBRTs of $148.3 \mathrm{~s}$ and $49.4 \mathrm{~s}$ were also carried out, at ILRs of $24.4 \pm 2.9$ and $25.3 \pm 2.6 \mathrm{~g} /\left(\mathrm{m}^{3} \mathrm{~h}\right)$, respectively. At each stage, inlet concentration of toluene was kept constant, and the biofilter was operated until pseudo steady-state when removal efficiency was constant. Microbial cell counts and carbon dioxide concentrations measured simultaneously. In order to insure satisfactory conditions of moisture and nutrients for microorganism activities, the nutrient solution was sprayed at a flow rate of $20 \mathrm{ml} / \mathrm{min}$ for $30 \mathrm{~min}$ every day, on the top of the packing 
media through the nutrient distribution system using a peristaltic pump.

4
Table 2 Operating conditions of the biofilter

\begin{tabular}{cccccc}
\hline \multirow{2}{*}{ Phase of operation } & $\begin{array}{c}\text { Gas flow } \\
\text { rate }\left(\mathrm{m}^{3} / \mathrm{h}\right)\end{array}$ & $\begin{array}{c}\text { Inlet } \\
\text { concentration } \\
\left(\mathrm{g} / \mathrm{m}^{3}\right)\end{array}$ & EBRT $(\mathrm{s})$ & ILR $\left(\mathrm{g} /\left(\mathrm{m}^{3} \mathrm{~h}\right)\right)$ & $\begin{array}{c}\text { Operation times } \\
\text { (days) }\end{array}$ \\
\hline & & $0.10 \pm 0.02$ & & $5.0 \pm 1.0$ & 7 \\
& & $0.31 \pm 0.04$ & & $15.2 \pm 1.8$ & 7 \\
Phase I & 0.2 & $0.53 \pm 0.06$ & 74.2 & $25.6 \pm 2.9$ & 7 \\
& & $0.71 \pm 0.04$ & & $34.4 \pm 2.0$ & 8 \\
Phase II & & $0.92 \pm 0.03$ & & $44.5 \pm 1.5$ & 10 \\
\hline
\end{tabular}

\subsection{Analytical methods}

Toluene concentration in the gas phase was measured using a gas chromatograph (GC1120; Sunny Hengping, China) equipped with a flame ionization detector (FID) and a FFAP chromatographic column $(30 \mathrm{~m} \times 0.25 \mathrm{~mm} \times 0.25 \mu \mathrm{m}$; Nanjingjianuo, China $)$. Nitrogen was used as carrier gas at a flow rate of $0.4 \mathrm{ml} / \mathrm{min}$. The oven, injector and FID detector was maintained at 65,150 and $250^{\circ} \mathrm{C}$, respectively.

Pressure drop and temperature were measured by means of testo 510 and testo 405-V1 (Testo AG, Germany), respectively. The Moisture Content of packing materials was determined by the weight loss method after drying 12 hours at $105^{\circ} \mathrm{C}$.

Carbon dioxide concentration in the gas phase was determined by the capacity titration method. $\mathrm{CO}_{2}$ was first absorbed into $\mathrm{Ba}(\mathrm{OH})_{2}$ solution $(1.4 \mathrm{~g} / \mathrm{L})$, with an atmosphere sampler (QC-2B; Beijing Municipal Institute of Labor Protection, China). $25 \mathrm{~mL}$ of the solution was titration by $\mathrm{CH}_{3} \mathrm{COOH}$ solution $(0.6 \mathrm{~g} / \mathrm{L})$, and phenolphthalein was used as indicator.

Microbial cell counts were measured by taken $1 \mathrm{~g}$ of moist media materials from three different locations at each layer of the biofilter. Each sample was mixed with $9 \mathrm{ml}$ sterile extraction buffer $(0.9 \% \mathrm{NaCl})$. The samples were subsequently shaken vigorously for $30 \mathrm{~min}$, and serially diluted with sterilized water. Finally, $1 \mathrm{~mL}$ solution was plated in a nutrient agar for isolation of bacteria(Rene et al. 2009; Saravanan \& Rajamohan 2009). The composition of 
103

104

105

106

107

108

109

nutrient agar per liter was as follows: peptone-5g, yeast extract-2.5g, glucose-1.0g and agar-15g.

The colonies were incubated for 3 days at $30^{\circ} \mathrm{C}$ before counted.

2.4 Performance evaluation

Parameters of the biofilter performance are illustrated in Table 3. Results are expressed in terms of inlet loading rate, elimination capacity and removal efficiency. Data from daily measurements were used to obtain average values of the biofilter.

Table 3 Definition of biofilter performance parameters.

\begin{tabular}{|c|c|c|}
\hline Parameter & Definition & Units \\
\hline Empty bed residence time & $\mathrm{EBRT}=\frac{V}{Q}$ & $\mathrm{~S}$ \\
\hline Inlet loading rate & $\mathrm{ILR}=\frac{Q \times C_{\text {in }}}{V}$ & $\mathrm{~g} /\left(\mathrm{m}^{3} \mathrm{~h}\right)$ \\
\hline Elimination capacity & $\mathrm{EC}=\frac{Q \times\left(C_{\text {in }}-C_{\text {out }}\right)}{V}$ & $\mathrm{~g} /\left(\mathrm{m}^{3} \mathrm{~h}\right)$ \\
\hline Removal efficiency & $\mathrm{RE}=\frac{C_{\text {in }}-C_{\text {out }}}{C_{\text {in }}} \times 100$ & $\%$ \\
\hline Carbon dioxide production rate & $O_{2}=\frac{Q \times\left(C_{\text {out }, \mathrm{CO}_{2}}-C_{\text {in, } \mathrm{CO}_{2}}\right)}{V}$ & $\mathrm{~g} /\left(\mathrm{m}^{3} \mathrm{~h}\right)$ \\
\hline
\end{tabular}

110

Where $Q$ is the total air flow rate $\left(\mathrm{m}^{3} / \mathrm{h}\right) ; V$ is the empty bed volume $\left(\mathrm{m}^{3}\right) ; C_{\text {in }}$ and $C_{\text {out }}$ are the inlet and outlet concentration of toluene, respectively. $C_{i n, \mathrm{CO}_{2}}$ and $C_{o u t, \mathrm{CO}_{2}}$ are the inlet and out concentration of carbon dioxide.

\section{Results and discussion}

\subsection{Influence of toluene inlet concentration}

EC and RE of toluene as a function of ILR, during the Phase I, are illustrated in Figure 2. ILR was gradually increased from 5.0 to $61.1 \mathrm{~g} /\left(\mathrm{m}^{3} \mathrm{~h}\right)$. RE was almost constantly with the increased of ILR up to $34.4 \mathrm{~g} /\left(\mathrm{m}^{3} \mathrm{~h}\right)$; then it decreased. The corresponding EC was linearly increased with ILR from 5.0 to $34.4 \mathrm{~g} /\left(\mathrm{m}^{3} \mathrm{~h}\right)$. Maximum EC was $36.0 \mathrm{~g} /\left(\mathrm{m}^{3} \mathrm{~h}\right)$ occurred at an ILR of $45.9 \mathrm{~g} /\left(\mathrm{m}^{3} \mathrm{~h}\right)$. After that EC decreased, and RE was only $50.6 \%$ under an ILR of $61.1 \mathrm{~g} /\left(\mathrm{m}^{3} \mathrm{~h}\right)$. Two distinct zones were observed in the RE versus ILR graph. Results got above were in agreement with Singh et al.(Singh et al. 2010a), Elmirini et al.(Elmrini et al. 2004) and Kiared et al.(Kiared et al. 1997). Comparison of biofilter performance is given in Table 4 . 


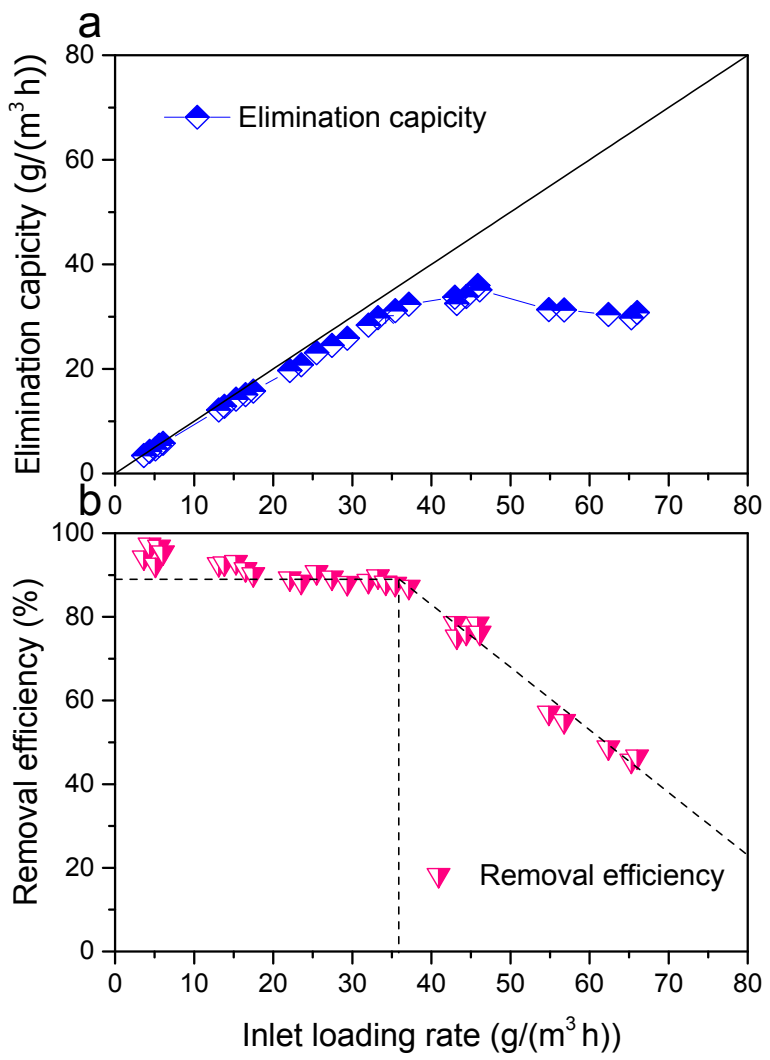

122

123

124

125

Figure 2 Influence of inlet loading rate on the elimination capacity (a) and removal efficiency (b) of the biofilter at an EBRT of $74.2 \mathrm{~s}$

Table 4 Comparison of biofilter performance

\begin{tabular}{|c|c|c|c|c|c|c|}
\hline References & Pollutants & Packing media & $\operatorname{EBRT}(\mathrm{s})$ & $\begin{array}{c}\mathrm{EC}_{\max } \\
\left(\mathrm{g} /\left(\mathrm{m}^{3} \mathrm{~h}\right)\right)\end{array}$ & $\begin{array}{c}\mathrm{RE} \text { of } \\
\mathrm{EC}_{\max }(\%)\end{array}$ & Micro-organisms \\
\hline (Zamir et al. 2011) & Toluene & Compost and lava & 264 & 1.9 & 92 & Fungi \\
\hline (Gallastegui et al. & Toluene & \multirow{2}{*}{ Small stones } & \multirow{2}{*}{180} & 40.3 & 69.6 & \multirow{2}{*}{ Bacteria } \\
\hline 2011) & p-xylene & & & 26.5 & 40.0 & \\
\hline (Singh et al. 2006b) & Toluene & Agro waste & 154 & 174.6 & 59.8 & Activated sludge \\
\hline This work & Toluene & Mixed media & 74.2 & 36.0 & 78.4 & Activated sludge \\
\hline
\end{tabular}

Zamir et al investigated a compost biofilter treating toluene vapor; maximum RE and EC was $92 \%$ and $1.9 \mathrm{~g} /\left(\mathrm{m}^{3} \mathrm{~h}\right)$, respectively. The $\mathrm{EC}_{\max }$ was far less than this study; this might

128 be explained by the biofilter they used was dominated by the white-rot fungus.

129 Gallstegui et al evaluated biofiltration of toluene and p-xylene; $\mathrm{EC}_{\max }$ of $40.3 \mathrm{~g} /\left(\mathrm{m}^{3} \mathrm{~h}\right)$ 
130

131

132

133

134

135

136

137

138

139

140

141

142

was observed. Reasons for their better performance could be longer operation EBRT and existence of p-xylene may stimulate the degradation of toluene. Singh et al. got higher $\mathrm{EC}_{\max }$ of $174.6 \mathrm{~g} /\left(\mathrm{m}^{3} \mathrm{~h}\right)$, however, the $\mathrm{RE}$ was much lower.

\subsection{Influence of gas flow rate}

Gas flow rate is an important parameter in biofilter operation. Three levels of gas flow rate, i.e. $0.1,0.2$ and $0.4 \mathrm{~m}^{3} / \mathrm{h}$, were performed. RE and EC as a function of EBRT are shown in Figure 3. ILR of $148.3,74.2$ and $49.4 \mathrm{~s}$ were set at the same levels, which were $24.4,25.6$ and $25.3 \mathrm{~g} /\left(\mathrm{m}^{3}\right.$ h), respectively. Depending on Figure 3, when EBRT decreased from 148.3 to $74.2 \mathrm{~s}$, biofilter maintained high RE. However, when EBRT decreased to $49.4 \mathrm{~s}$, RE decreased to $71.0 \%$, this might be due to reduction in the contaminant retention time could not provide sufficient time for toluene to transfer into biofilm. The results were coordinated with the findings of some literatures, biofilter performance decrease with decreasing EBRTs (Abumaizar et al. 1998; Rene et al. 2012).

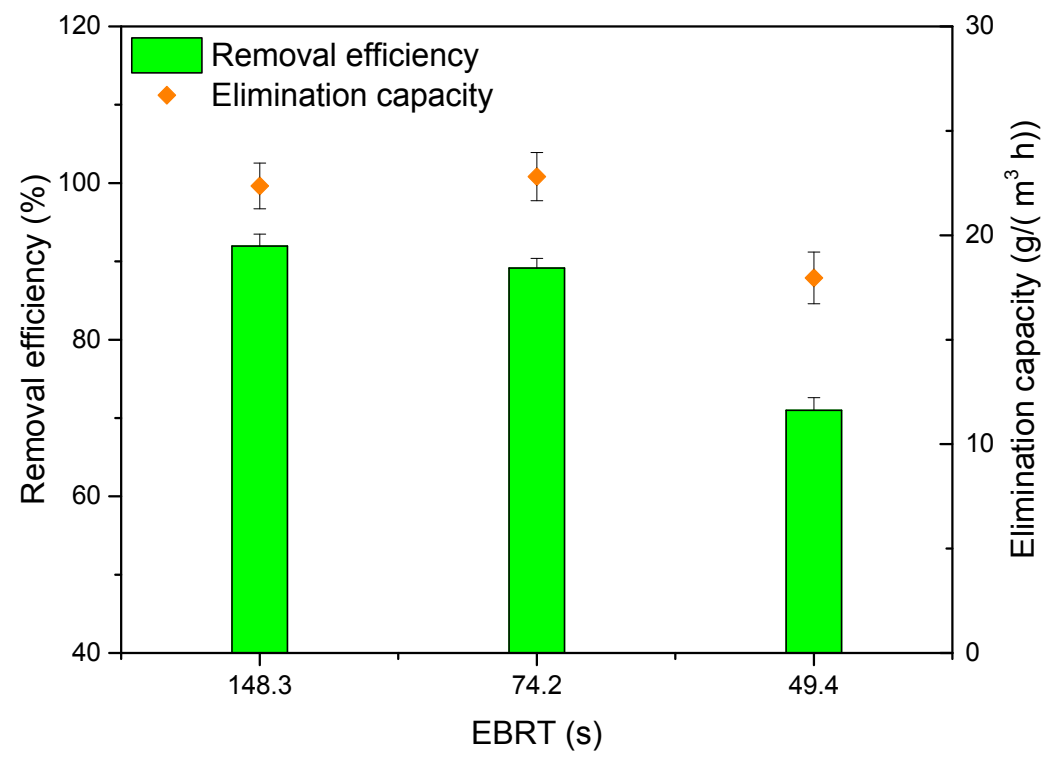

143 Figure 3 Influence of EBRT on removal efficiency and elimination capacity 3.3 Evaluation of $\mathrm{CO}_{2}$ Toluene is finally biodegraded to $\mathrm{CO}_{2}$ and $\mathrm{H}_{2} \mathrm{O}$ and utilized to format biomass for microbial 
147 148 149 150 151 152 153 154 155 156 157 158 159 160 161 162 163 164 165 166

growth (Andreoni \& Gianfreda 2007), thus monitoring $\mathrm{CO}_{2}$ concentration provides valuable information for the degree of VOCs mineralization. The stoichiometric reaction of toluene oxidation can be written as follows:

$$
\mathrm{C}_{7} \mathrm{H}_{8}+9 \mathrm{O}_{2} \rightarrow 7 \mathrm{CO}_{2}+4 \mathrm{H}_{2} \mathrm{O}
$$

$\mathrm{P}_{\mathrm{CO}_{2}}$ during Phase $\mathrm{I}$ as a function of $\mathrm{EC}$ for toluene is shown in Figure 4. The $\mathrm{P}_{\mathrm{CO}_{2}}$ was concluded to linearly increase along with the EC at Phase I. A linear regression, calculated according to the least square method, provided the following equations for toluene degradation:

$$
\mathrm{P}_{\mathrm{CO}_{2}}=1.45 \mathrm{EC}-1.23
$$

The mass-ratio of $\mathrm{P}_{\mathrm{CO}_{2}}$ to EC of toluene was 1.45 , less than the theoretical calculation. The theoretical mass-ratio should be 3.35 , when the toluene was totally oxidation to $\mathrm{H}_{2} \mathrm{O}$ and $\mathrm{CO}_{2}$. Gallastegui et al (Gallastegui et al. 2013) reported the biodegradation of ethylbenzene and toluene. According to their study, linear fits to experimental data was made, and mass-ratios of ethylbenzene and toluene were 1.36 and 2.84, respectively. Zhuowei et al (Cheng et al. 2016) reported biodegradation of toluene in fungal biofilter (F-BF), bacterial biofilters (B-BF) and fungal \& bacterial biofilters (F\&B-BF). The mass-ratio of F-BF, F\&B-BF, and B-BF was 1.23, 2.52, and 2.85 , respectively.

The cause of discrepancy might be that the biodegradation of toluene took some steps to convert into biomass or product $\mathrm{CO}_{2}$, and some intermediates may not degrade immediately. In addition, some of the $\mathrm{CO}_{2}$ could accumulate in the liquid in other forms, such as $\mathrm{CO}_{3}^{2}, \mathrm{HCO}_{3}^{-}$ and $\mathrm{H}_{2} \mathrm{CO}_{3}$ (Wu et al. 2006). 


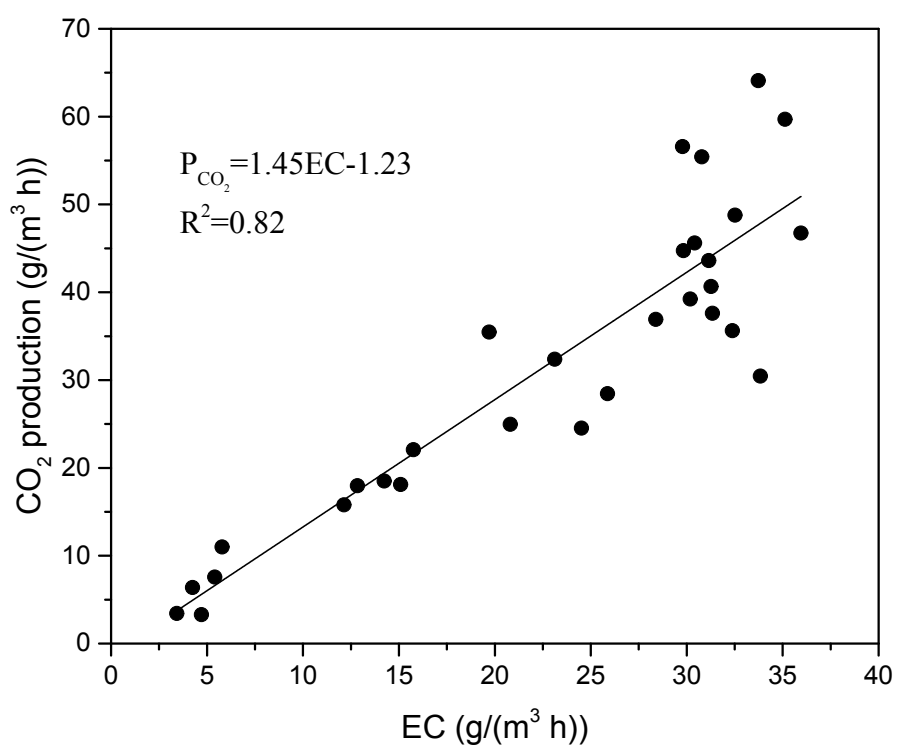

167

168

169

170

171

172

Figure 4 Carbon dioxide production rate as a function of EC for toluene

\subsection{Evaluation of different layers}

Biofilter was subdivided into three identical layers; gas samples were collected from each port of the biofilter. In order to have an insight into the contribution of different layer to its overall performance, RE and EC of the three layers as a function of ILR is shown in Figure 5. 


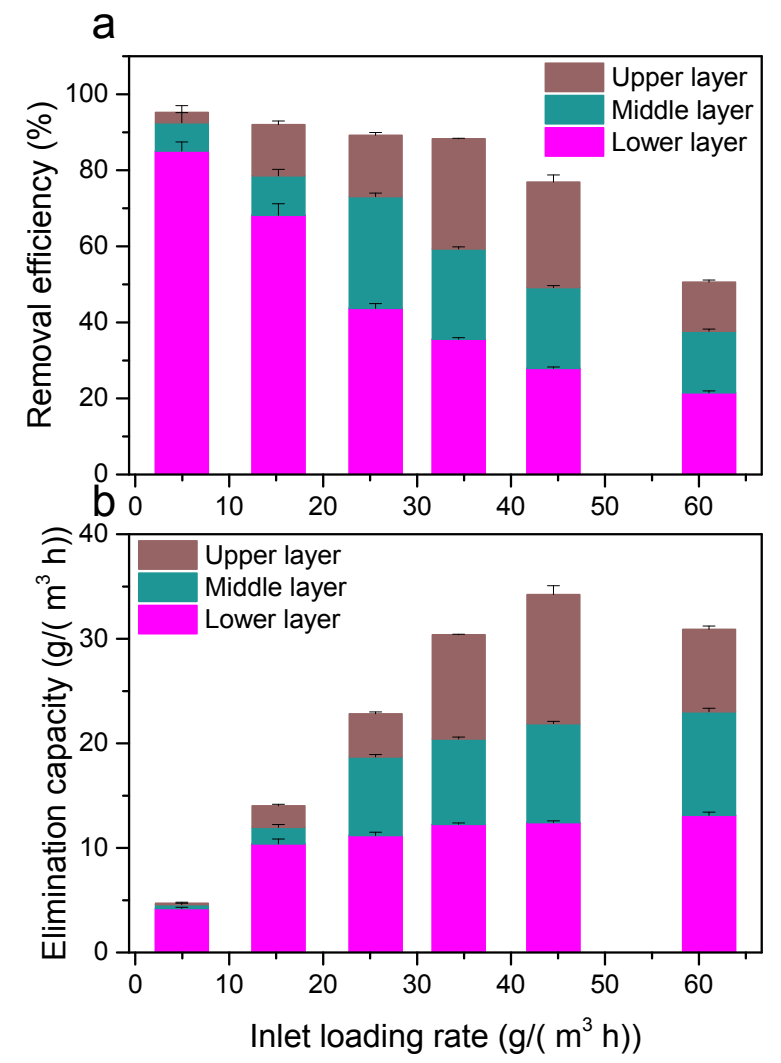

Figure 5 Comparison of removal efficiency (a) and elimination capacity (b) among the three layers at various inlet loading rate of the lower layer decreased from 85.1 to $21.5 \%$; while the middle layer improved from 7.5 to 29.4 (at an ILR of $25.6 \mathrm{~g} /\left(\mathrm{m}^{3} \mathrm{~h}\right)$ ) then decreased to $16.2 \%$; and the upper layer improved from 2.7 to 29.0 (at an ILR of $34.4 \mathrm{~g} /\left(\mathrm{m}^{3} \mathrm{~h}\right)$ ) then decreased to $12.9 \%$. At low ILR, RE was mostly contributed by the lower layer. The majority of the toluene were eliminated in the lower layer; only a small portion of toluene was offered to the middle and upper layers. When at higher ILR, toluene cannot be completely degraded by the lower layer, the rest flowed into other two layers. However, EC of the lower layer was still higher than other layers. Cause of EC in the lower layer was always the highest, may be due to the higher microbial population and nutrients. 
2007). Eldon R. Rene et al.(Rene et al. 2015) studied the performance of a biofilter treating benzene and toluene, in an up-flow mode (same with the study). However, results showed that the elimination of toluene was mostly occurred at the topside of the biofiter, which was not conformed to the results in this study. This may be due to the biofiter they used, was first to treat benzene; whereas the biofilter in this study used was only to treat toluene.

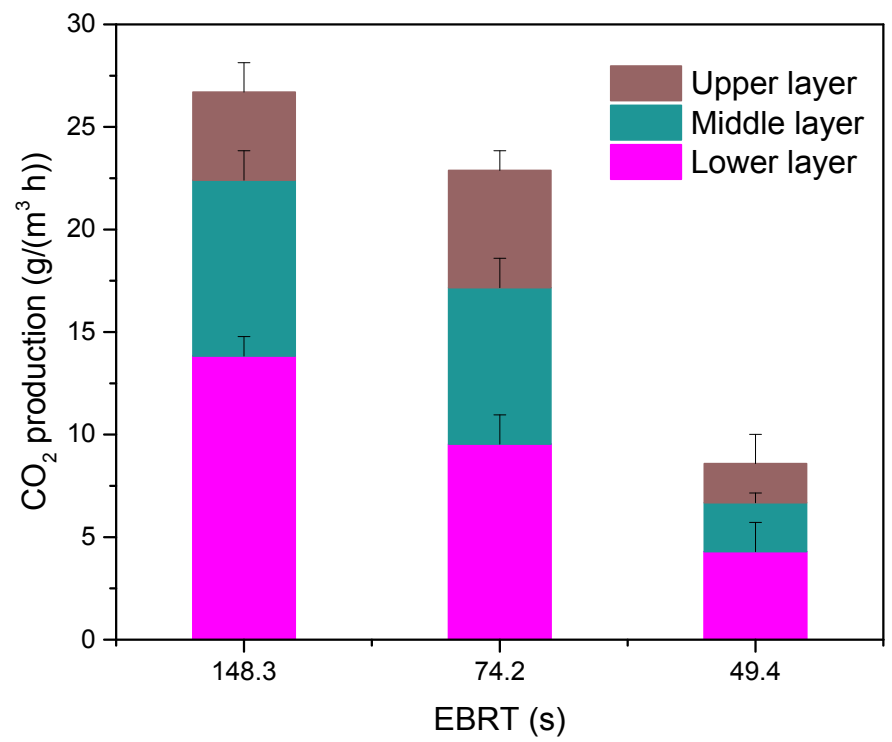

Figure 6 Carbon dioxide production rate at the three layers as a function of EBRT Carbon dioxide production rate at the three layers as a function of EBTT is showed in Figure 6. From Figure 6, it was clear that the highest EBRT the highest carbon dioxide concentration, since the micro-organism at this moment could obtain large amounts of contaminants. The carbon dioxide generated by the lower layer preceded the other two layers at the three EBRTs, and this was in accordance with the lower layer had larger elimination capacity of the results got above.

\subsection{Microbial counts behavior}

According to the results of the microbial cell counts, there were mainly three kind of microorganism, one kind of fungi and two kinds of bacteria. The fungus was white and filamentous, and the microbial count versus time is shown in Figure 7. The microbial count of the two bacteria - one bacterium was pale yellow named bacterium-A, the other one was pinky named 
204 bacterium-B - versus time is shown in Figure 8.

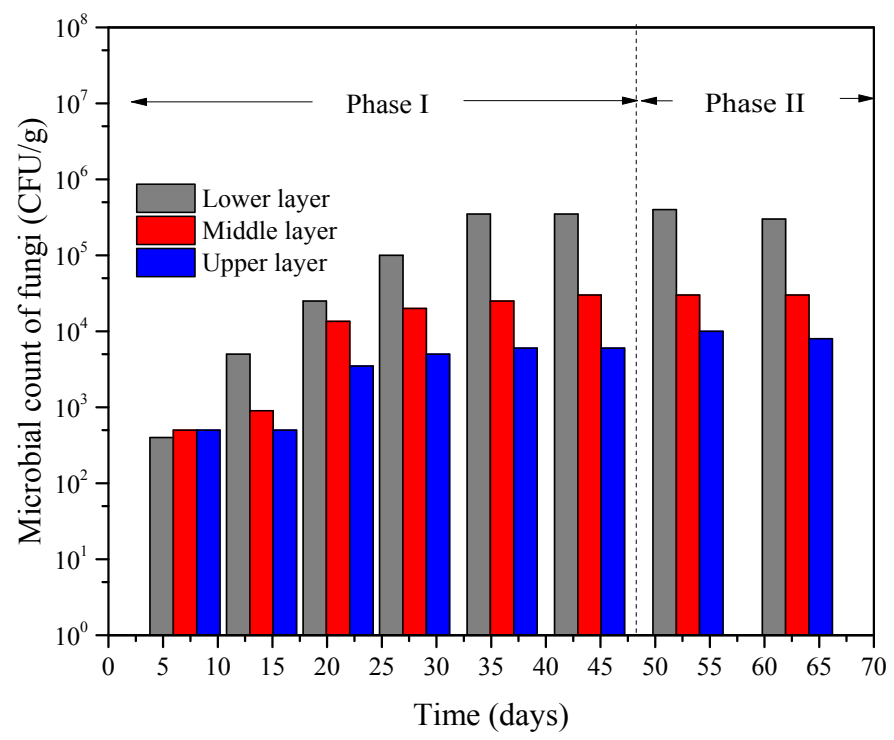

205

Figure 7 Microbial count of fungi at the three layers of the bioflter versus time

At the beginning of the operation, the microbial count of fungi at the three layers was at the same level which was less than $10^{3} \mathrm{CFU} / \mathrm{g}$. Then, gradually increased to about $3.5 \times 10^{5} \mathrm{CFU} / \mathrm{g}$ at the lower layer, $3 \times 10^{4} \mathrm{CFU} / \mathrm{g}$ at middle layer, $6 \times 10^{3} \mathrm{CFU} / \mathrm{g}$ at the upper layer, respectively,

210 at the $36^{\text {th }}$ day which the ILR was $44.5 \mathrm{~g} /\left(\mathrm{m}^{3} \mathrm{~h}\right)$. The count of bacterium-A had the similar trend

211 with fungi; however, the differences were the initial counts at the three layers were a little more

212 than $10^{4} \mathrm{CFU} / \mathrm{g}$ and the maximum number occurred in the $28^{\text {th }}$ day at an ILR of $34.4 \mathrm{~g} /\left(\mathrm{m}^{3} \mathrm{~h}\right)$. 


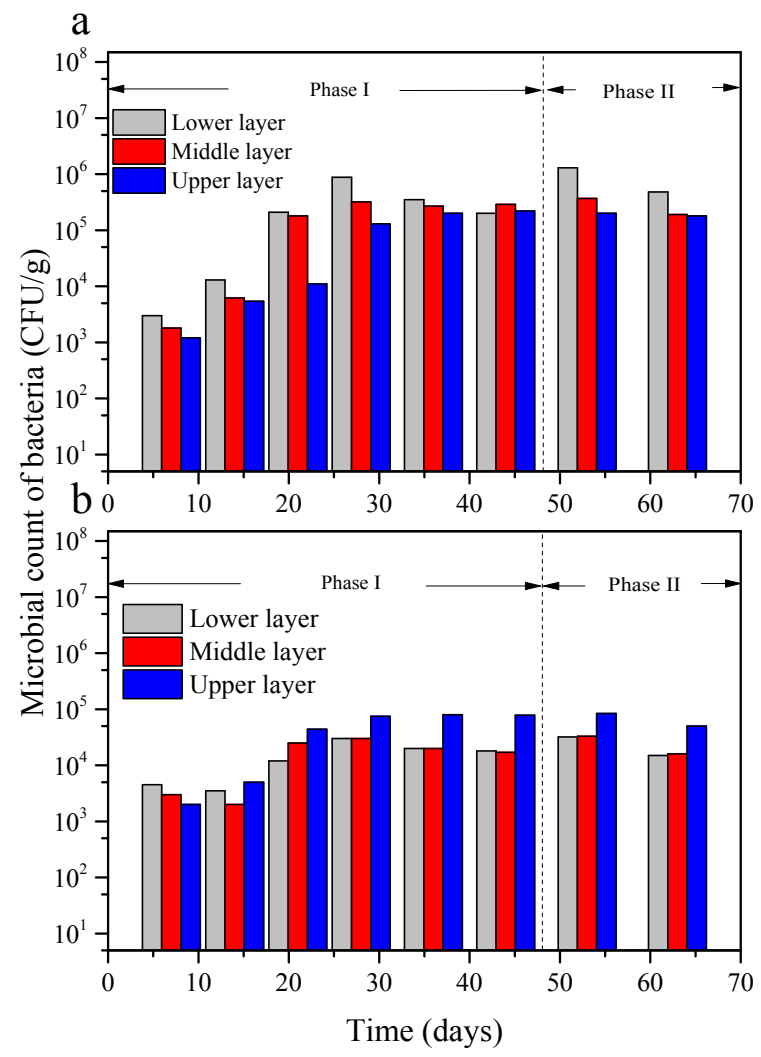
time

216 However, when compared to bacterium-B, it showed some differences. Initially, count of

217 bacterium-B was close to bacterium-A, $4.5 \times 10^{3} \mathrm{CFU} / \mathrm{g}$ in the lower layer, $3 \times 10^{3} \mathrm{CFU} / \mathrm{g}$ in the middle layer, $6 \times 10^{2} \mathrm{CFU} / \mathrm{g}$ in the upper layer, respectively. The count increased with the increase of the ILR, then maintained stable, which was similar with fungi and bacterium-A. However, most of the time, the microbial count of the upper layer was higher than that of the other two layers, and a maximum value of $8 \times 10^{2} \mathrm{CFU} / \mathrm{g}$ was achieved at an ILR of $44.5 \mathrm{~g} /\left(\mathrm{m}^{3}\right.$ h).

Both microbial counts of the fungi and the bacteria were depended on ILR, which demonstrated that the micro-organisms were fed on the contaminants. The trend of the microorganisms at different layers under various ILRs was consistent with the trend of RE and EC. 
226

227

228

229

230

231

232

233

234

235

236

237

238

239

240

241

242

243

According to G. Gallastegui et al.(Gallastegui et al. 2013), the microbial population and reaction capacity remained low at the lower layer, this was consistent with bacterium-B, however, was not consistent with the trends of the fungi and bacterium-A. In their study, the concentration of the contaminant could achieve to $8.72 \mathrm{~g} / \mathrm{m}^{3}$, because that the lower layer had the highest microbial population. The reason bacterium-B was higher at the upper layer may be that it was more sensitive to the concentration of the contaminant. Results of V. Saravanan and N.

Rajamohan(Saravanan \& Rajamohan 2009) showed that the removals were more efficient in the lower layer which was consistent with the results got here.

3.6 Behavior of the pressure drop

Pressure drop of the biofilter depends on many factors. Gas flow rate directly decided the velocity of the gas; the bigger the gas flow rate, the higher the pressure drop. Second was the media properties which include media size, porosity, depth and moisture content (Singh et al. 2006a), et al. Besides, biomass accumulation in the biofilter may lead to changes in media bed characteristics, which may cause channel diminished, thus increased pressure drop (MorganSagastume et al. 2001). The pressure drop versus time is shown in Figure 9.

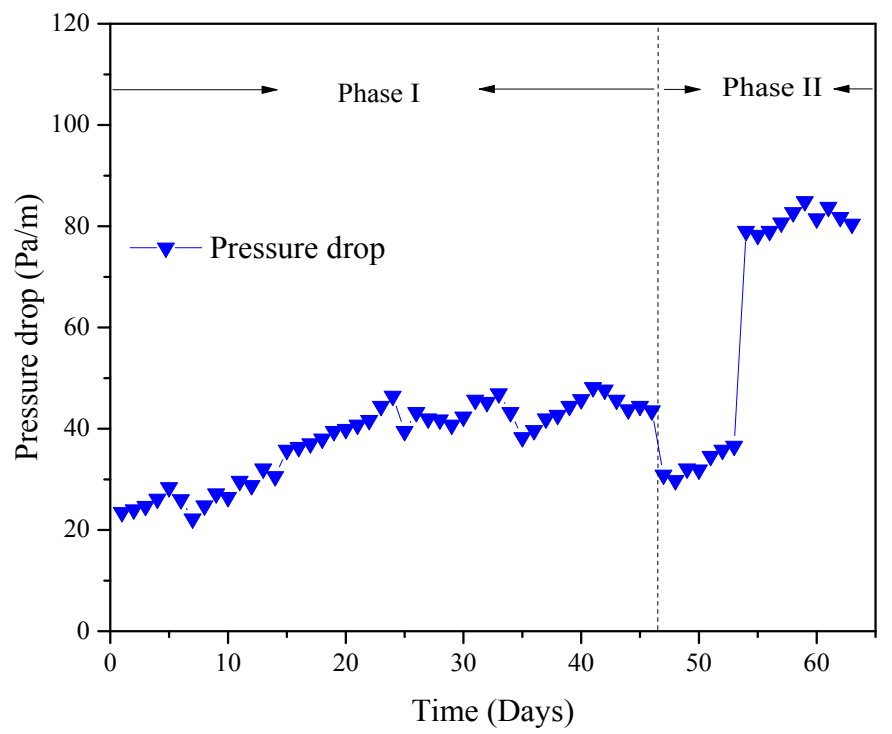

Figure 9 Pressure drop versus time at various phase

The initial pressure drop, during phase I, was about $20 \mathrm{~Pa} / \mathrm{m}$, then increased slowly with the 
244

245

246

247

248

249

250

251

252

253

254

255

256

257

operation time, and finally achieved a steady state about $43 \mathrm{~Pa} / \mathrm{m}$. During phase II, the pressure drop decreased to nearly $30 \mathrm{~Pa} / \mathrm{m}$ with the doubled EBRT, then increased to $81 \mathrm{~Pa} / \mathrm{m}$ at an EBRT of $49.4 \mathrm{~s}$; the sudden increase of pressure drop was due to reduction of EBRT. During phase I, the gas flow rate was maintained constant, thus the increase of the pressure drops was mainly due to biomass accumulation. In addition, the bed compaction and deterioration was observed negligible, which indicated the mixed packing material had a good mechanical strength. The maximum value of the pressure drops was $84.9 \mathrm{~Pa} / \mathrm{m}$, which was significantly advanced to some organic materials for wood chips with a pressure drop of $2600 \mathrm{~Pa} / \mathrm{m}($ Morgan-Sagastume et al. 2001), and matured compost with a pressure drop of 264.8 Pa/m(Delhoménie et al. 2003).

\section{Conclusion}

In this paper, toluene was treated with an up-flow lab scale biofilter filled with inert packing materials. The $\mathrm{EC}_{\max }$ was observed at an inlet loading rate of $45.9 \mathrm{~g} /\left(\mathrm{m}^{3} \mathrm{~h}\right)$, and two distinct zones were also observed. During the whole operation, the highest EC was appeared at the lower layer. The $\mathrm{CO}_{2}$ production rate and the distribution of microbial populations in the biofilter were well correlated with the toluene removal efficiencies and elimination capacities, indicated that the biodegradation of toluene in the biofilter. The low pressure drop demonstrated that the packing materials were proper for biofiltration.

\section{References}

Abumaizar RJ, Kocher W, and Smith EH. 1998. Biofiltration of BTEX contaminated air streams using compostactivated carbon filter media. Journal of Hazardous Materials 60:111-126.

Aly Hassan A, and Sorial G. 2009. Biological treatment of benzene in a controlled trickle bed air biofilter. Chemosphere 75:1315-1321.

Amin MM, Rahimi A, Bina B, Heidari M, and Moghadam FM. 2014. Performance evaluation of a scoria-compost biofilter treating xylene vapors. Journal Of Environmental Health Science And Engineering 12.

Andreoni V, and Gianfreda L. 2007. Bioremediation and monitoring of aromatic-polluted habitats. Appl Microbiol Biotechnol 76:287-308.

Anet B, Couriol C, Lendormi T, Amrane A, Le Cloirec P, Cogny G, and Fillières R. 2013. Characterization and Selection of Packing Materials for Biofiltration of Rendering Odourous Emissions. Water, Air, \& Soil Pollution 224.

Chen CL, Fang HY, and Shu CM. 2005. Source location and characterization of volatile organic compound emissions at a petrochemical plant in Kaohsiung, Taiwan. Journal of the Air \& Waste Management Association 55:1487-1497. 
276

277

278

279

280

281

282

283

284

285

286

287

288

289

290

291

292

293

294

295

296

297

298

299

300

301

302

303

304

305

306

307

308

309

310

311

312

313

314

315

316

Cheng Z, Lu L, Kennes C, Yu J, and Chen J. 2016. Treatment of gaseous toluene in three biofilters inoculated with fungi/bacteria: Microbial analysis, performance and starvation response. J Hazard Mater 303:83-93.

Cho E, Galera MM, Lorenzana A, and Chung W-J. 2009. Ethylbenzene, o-Xylene, and BTEX Removal by Sphingomonas sp. D3K1 in Rock Wool-Compost Biofilters. Environmental Engineering Science 26:45-52.

Delhoménie M-C, Bibeau L, Gendron J, Brzezinski R, and Heitz M. 2003. A study of clogging in a biofilter treating toluene vapors. Chemical Engineering Journal 94:211-222.

Delhomenie MC, Bibeau L, Gendron J, Brzezinski R, and Heitz M. 2003. Degradation of toluene, xylene, and trimethyl benzene vapors by biofiltration: A comparison. Journal of the Air \& Waste Management Association 53:217-226.

Dorado AD, Lafuente FJ, Gabriel D, and Gamisans X. 2010. A comparative study based on physical characteristics of suitable packing materials in biofiltration. Environmental Technology 31:193-204.

El-Naas MH, Acio JA, and El Telib AE. 2014. Aerobic biodegradation of BTEX: Progresses and Prospects. Journal of Environmental Chemical Engineering 2:1104-1122.

Elmrini H, Bredin N, Shareefdeen Z, and Heitz M. 2004. Biofiltration of xylene emissions: bioreactor response to variations in the pollutant inlet concentration and gas flow rate. Chemical Engineering Journal 100:149-158.

Gallastegui G, Avalos Ramirez A, Elias A, Jones JP, and Heitz M. 2011. Performance and macrokinetic analysis of biofiltration of toluene and p-xylene mixtures in a conventional biofilter packed with inert material. Bioresour Technol 102:7657-7665.

Gallastegui G, Barona A, Rojo N, Gurtubay L, and Elías A. 2013. Comparative response of two organic biofilters treating ethylbenzene and toluene after prolonged exposure. Process Safety and Environmental Protection 91:112-122.

Kiared K, Wu G, Beerli M, Rothenbühler M, and Heitz M. 1997. Application of biofiltration to the control of VOC emissions. Environmental Technology 18:55-63.

Lebrero R, Estrada JM, Munoz R, and Quijano G. 2014. Deterioration of organic packing materials commonly used in air biofiltration: effect of VOC-packing interactions. J Environ Manage 137:93-100.

Maestre JP, Gamisans X, Gabriel D, and Lafuente J. 2007. Fungal biofilters for toluene biofiltration: evaluation of the performance with four packing materials under different operating conditions. Chemosphere 67:684-692.

Morgan-Sagastume F, Sleep BE, and Allen DG. 2001. Effects of biomass growth on gas pressure drop in biofilters. Journal of Environmental Engineering-Asce 127:388-396.

Mudliar S, Giri B, Padoley K, Satpute D, Dixit R, Bhatt P, Pandey R, Juwarkar A, and Vaidya A. 2010. Bioreactors for treatment of VOCs and odours - a review. J Environ Manage 91:1039-1054.

Rahul, Mathur AK, and Balomajumder C. 2013a. Biological treatment and modeling aspect of BTEX abatement process in a biofilter. Bioresour Technol 142:9-17.

Rahul, Mathur AK, and Balomajumder C. 2013b. Performance evaluation and model analysis of BTEX contaminated air in corn-cob biofilter system. Bioresour Technol 133:166-174.

Rene ER, Kar S, Krishnan J, Pakshirajan K, Lopez ME, Murthy DV, and Swaminathan T. 2015. Start-up, performance and optimization of a compost biofilter treating gas-phase mixture of benzene and toluene. Bioresour Technol 190:529-535.

Rene ER, Mohammad BT, Veiga MC, and Kennes C. 2012. Biodegradation of BTEX in a fungal biofilter: influence of operational parameters, effect of shock-loads and substrate stratification. Bioresour Technol 116:204-213.

Rene ER, Murthy D, and Swaminathan T. 2005. Performance evaluation of a compost biofilter treating toluene 
vapours. Process Biochemistry 40:2771-2779.

Rene ER, Murthy DVS, and Swaminathan T. 2009. Steady- and transient-state effects during the biological oxidation of gas-phase benzene in a continuously operated biofilter. Clean Technologies and Environmental Policy 12:525-535.

Saravanan V, and Rajamohan N. 2009. Treatment of xylene polluted air using press mud-based biofilter. J Hazard Mater 162:981-988.

Singh K, Singh RS, Rai BN, and Upadhyay SN. 2010a. Biofiltration of toluene using wood charcoal as the biofilter media. Bioresour Technol 101:3947-3951.

Singh RS, Agnihotri SS, and Upadhyay SN. 2006a. Removal of toluene vapour using agro-waste as biofilter media. Bioresour Technol 97:2296-2301.

Singh RS, Rai BN, and Upadhyay SN. 2006b. Performance Evaluation of an Agro Waste Based Biofilter Treating Toluene Vapours. Environmental Technology 27:349-357.

Singh RS, Rai BN, and Upadhyay SN. 2010b. Removal of toluene vapour from air stream using a biofilter packed with polyurethane foam. Process Safety and Environmental Protection 88:366-371.

Slominska M, Krol S, and Namiesnik J. 2013. Removal of BTEX Compounds From Waste Gases; Destruction and Recovery Techniques. Critical Reviews in Environmental Science and Technology 43:1417-1445.

Vergara-Fernandez A, Lara Molina L, Pulido NA, and Aroca G. 2007. Effects of gas flow rate, inlet concentration and temperature on the biofiltration of toluene vapors. $J$ Environ Manage 84:115-122.

Wu D, Quan X, Zhao Y, and Chen S. 2006. Removal of p-xylene from an air stream in a hybrid biofilter. Journal of Hazardous Materials 136:288-295.

Xi J, Hu H-Y, and Qian Y. 2006. Effect of operating conditions on long-term performance of a biofilter treating gaseous toluene: Biomass accumulation and stable-run time estimation. Biochemical Engineering Journal 31:165-172.

Yassaa N, Brancaleoni E, Frattoni M, and Ciccioli P. 2006. Isomeric analysis of BTEXs in the atmosphere using betacyclodextrin capillary chromatography coupled with thermal desorption and mass spectrometry. Chemosphere 63:502-508.

Zamir SM, Halladj R, and Nasernejad B. 2011. Removal of toluene vapors using a fungal biofilter under intermittent loading. Process Safety and Environmental Protection 89:8-14.

Zare H, Najafpour G, Rahimnejad M, Tardast A, and Gilani S. 2012. Biofiltration of ethyl acetate by Pseudomonas putida immobilized on walnut shell. Bioresour Technol 123:419-423. 